\title{
Nempung Messages in Communication Manggarai Traditional Marriage: Case Study of Three Clay Events on Communication Manggarai Traditional Marriage in Kupang City, NTT, Indonesia
}

\author{
Darus Antonius' 1 Yuliana Wahyu² \\ ${ }^{1}$ Unika Widya Mandira, Kupang, Indonesia \\ ${ }^{2}$ Unika Katolik Indonesia Santu Paulus, Ruteng, Indonesia \\ Email: darusantonius01@gmail.com,wahyuyuliana641@yahoo.co.id
}

How to cite this paper: Antonius, D., \& Wahyu, Y. (2020). Nempung Messages in Communication Manggarai Traditional Marriage: Case Study of Three Clay Events on Communication Manggarai Traditional Marriage in Kupang City, NTT, Indonesia. Open Journal of Social Sciences, 8, 265-281. https://doi.org/10.4236/jss.2020.83025

Received: February 20, 2020

Accepted: March 22, 2020

Published: March 25, 2020

Copyright $\odot 2020$ by author(s) and Scientific Research Publishing Inc. This work is licensed under the Creative Commons Attribution International License (CC BY 4.0).

http://creativecommons.org/licenses/by/4.0/

\begin{abstract}
The problems of this study: 1) what are the similarities and differences in the characteristics of the practice of Nempung message communication in the three cases of Manggarai Customary Marriage communication in Kupang? 2) What symbols were found during the implementation of Nempung in these three traditional marriage communication events? 3) What is the meaning of the Nempung symbols in the three Manggarai traditional marriage communication events in Kupang city? 4) What is the importance Nempung message for the wedding couple of the next generation of Manggarai today? Discussion of the results of the study, first, the three cases of Nempung have unique characteristics due to different conditions underlying them. But, the three also showed a fundamental similarity. In the Nempung event, a symbolic communication interaction process took place between two different families. The communication process of Nempung provides important messages for new families and for the bond of relations between the two extended families (male and female families). Second, important communication symbols in Nempung include: 1) Human symbols as prototypes; 2) Pet symbols; 3) Symbols of material and life necessities such as machetes (kope), traditional cloth Manggrai (towe songke), dulang, sack rice, each of which has its own meaning in the life of a new family in the future. Third, the symbols of Nempung communication mean deeply to the lives of Manggarai people in general and newlyweds in developing new family visions and missions, especially in daily life. Fourth, implementing Nempung according to Manggarai custom is very important for the traditional legitimacy of the marriage of two people who want to live as
\end{abstract}


husband and wife. Without Nempung, marriages have not received the legitimacy of the Manggarai custom. The influence of the times, Nempung tends to be ignored by some Manggarai marriages. Even the marriage of two people is bypassed by shortcuts, elopement, gathering kebo, without customary affairs. Suggestions are given: 1) For the Manggarai bride and groom, the results of this study are useful as information material to live up to the importance of adat legitimacy for their marriage as a legal entity. 2) For Manggarai parents, the results of this study serve as inspiration for strengthening their belief in the importance of traditional legitimacy to their marriages and future generations. 3) For the Manggarai community, the results of this study become informational material to understand the nature of marriage from the perspective of traditional Manggarai and inspiration material to continue to believe that Nempung is a moment of traditional legitimacy that must be maintained for traditionally legimated marriages. 4) For the following researchers, the results of this study provide a foundation for further research on the relevance of the current Nempung communication event.

\section{Keywords}

Nempung, Cultural Communication, Marriage

\section{Introduction}

\subsection{Background}

Manggarai Raya is a cultural unit, which consists of three sub-cultures and is spread over three districts namely West Manggarai, Manggarai and East Manggarai. One of the important themes in the Manggarai Raya cultural unit is the phenomenon of the Nempung message in the communication of traditional marriages. An intact Manggarai traditional marriage should end with Nempung or Wagal, where the bride and groom get the traditional legitimacy to form a new family in the adat community. But for various reasons, marriages often do not end in Wagal/Nempung. The researcher observes that after requesting (Pongo), the marriage procedure is immediately continued with the marriage of the Church. There are even couples who take shortcuts by eloping and gathering together, without going through the slightest customary procedures.

In the city of Kupang, not all traditional Manggarai wedding events pass through Nempung or Wagal. There are many phenomena of Manggarai marriage that are not followed by a traditional Nempung event. There is a limited marriage at the stage of Requesting Request (Pongo), then the bride and groom immediately carry out the marriage of the Church. The three case studies of this research are the traditional marriage of Manggarai which ended with the traditional Nempung/ Wagal event, so that the entire marriage customary procedure has been passed completely and intact.

The three case studies are, first, the phenomenon of customary marriage between Robert Jehatu (Roby) and Elvira Ukar (Vira) (Figure 1). Robert Jehatu is 
the third son of Mr. Anton Jehatu's couple. They live in Sikumana Kupang. While Elvira Ukar is the second child (daughter) of Mr. Marsel Ukar (from Betu village) and Mrs. Valentina Jebida (Benteng Jawa) Lamba Leda, East Manggarai Regency. They live in Oebufu Village, Oebobo District, Kupang City.

Second, the phenomenon of Manggarai traditional marriage communication between Yuvens Tukung and Maria Fransiska Darlen. Yuvens Tukung is a man born in Langke Village, Ruteng District, Manggarai Regency. The fifth son of the couple Avelinus Juru and mother Veronika Wasul is domiciled in Langke Village, Ruteng District, Manggarai Regency. maria Fransiska Darlen (Siska), is the eldest daughter of Mr. Darus Antonius (from Deru village) and Mrs. Elisabeth Lensi (from Wae Paci village), Lamba Leda Sub-district, East Manggarai, domiciled in Maulafa Village, Maulafa District, Kupang City, NTT Province (Figure 2).

Third, the phenomenon of traditional marriage communication between $\mathrm{Cri}$ -

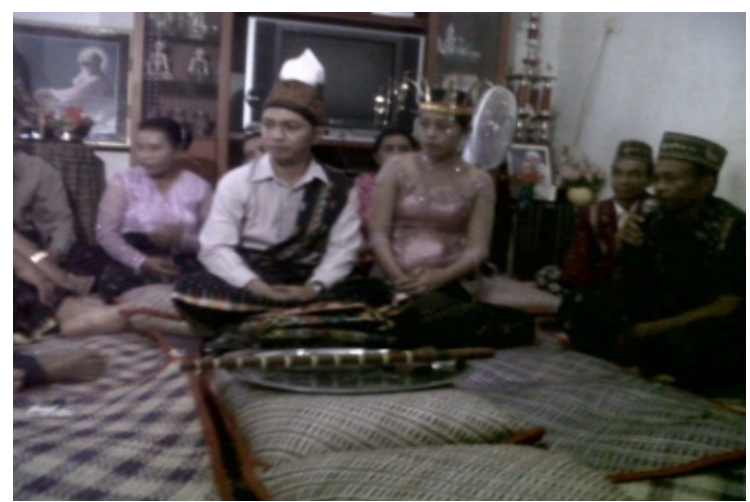

Source: Roby and Vira's documentation. Kupang, January 23, 2019.

Figure 1. Roby-Vira.

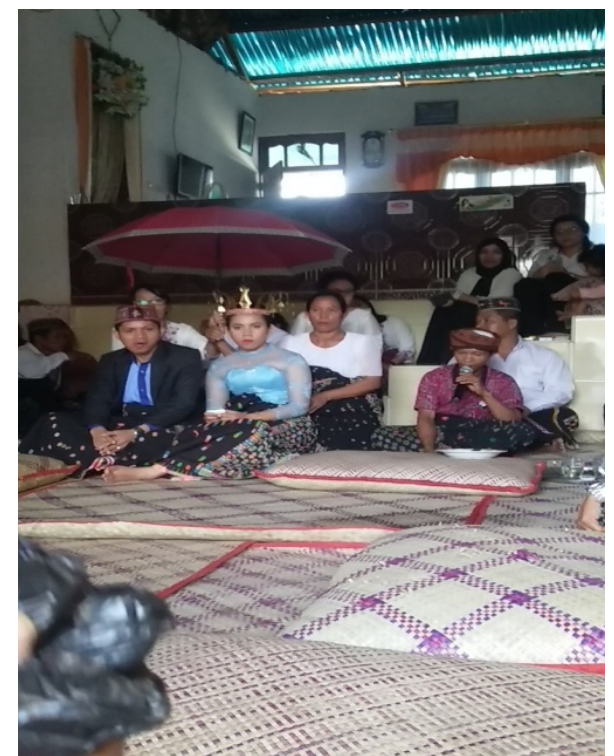

Source: Yuvens and Siska documentation. Kupang: 3 July 2019

Figure 2. Yuven-Siska. 
tophore Agut (Ito) and Roswita Paskalina Darlen. Kristo is the eldest son of the father pair Petrus Agut (from Colol, Poco Ranaka District, East Manggarai) and Monica Sara (from Ende Regency). They are domiciled in Line 40 of Kolhua Urban Village, Maulafa, Kupang city. While Roswita Paskalina Darlen (Wiwi) is the second daughter of Mr. Darus Antonius (from Kampung Deru) with Mrs. Elisabeth Lensi (from Wae Paci village), Lamba Leda Sub-District, East Manggarai. They are domiciled in RT 012 RW IV, Maulafa Village, Maulafa District, Kupang City (Figure 3).

\subsection{Formulation of the Problem}

As for the research problems: 1) What are the similarities and differences in the characteristics of the practice of Nempung in the three examples of Manggarai Indigenous Marriage communication events which are the object of case studies in this study? 2) What symbols did we find during the Nempung event in the three Manggarai traditional wedding communication events in Kupang that were the object of the case studies in this study? 3) What are the meanings and meanings contained in the symbols of Nempung in the three Manggarai traditional wedding communication events that were held in the city of Kupang? 4) What is the significance of the Nempung symbols for the married couple of the current generation of Manggarai? This problem will be discussed in this research.

\subsection{Research Purposes}

The general objectives of this study: 1) want to obtain a complete picture of the similarities and differences in the character of Nempung which is practiced in three cases of Manggarai Raya traditional marriage communication events in Kupang city examined in this study; 2) Obtaining a description of the symbols

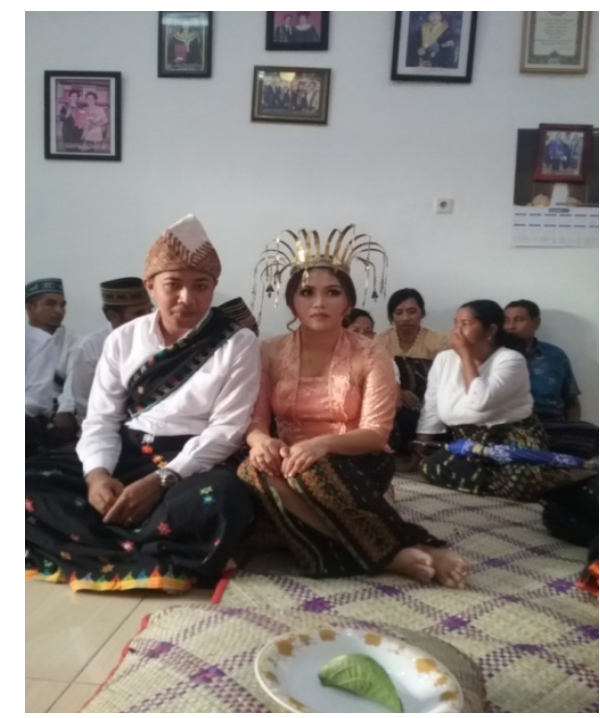

Source: Kristo and Wiwi documentation. Kupang, 18 November 2019.

Figure 3. Kristo-Wiwi Nempung. 
that we found during the implementation of the Nempung event in the Manggarai traditional marriage in Kupang; 3) Obtaining knowledge of the meaning contained in the Nempung symbols in three events of Manggarai traditional marriage communication in the city Kupang? 4) Acquiring knowledge and explanation about the importance of Nempung symbols for the marriage couple of the next generation of Manggarai in managing new households today.

\subsection{Benefits of Research}

\subsubsection{Theoretical/Academic Benefits}

Scientific research in general, including communication science research, is expected to bring benefits to the development of academic thought in the context of developing scientific theories about the relationship between concepts and phenomena that occur in various contexts. A research is expected to be useful for the development of science through the use of certain methods in an effort to study, apply, test, explain or form theories, concepts and certain hypotheses in relevant fields of science related to the events of Clay.

Here the researcher can begin his research by asking whether a social science theory in general and communication science theory, in particular, is still appropriate to be used to answer questions about communication phenomena/problems or researchers observe/solve problems/communication phenomena that are finally forming a new communication theory. What methods are suitable for solving research problems, etc. In this perspective of thinking, the academic/theoretical benefits of this research are expected to inspire academic thinking in an effort to develop social science theory in general and communication science theory in particular so as to contribute thought to the Department Communication Studies, Faculty of Social and Political Sciences.

\subsubsection{Practical Benefits}

Practically, this research is expected to be beneficial for various parties: 1) For the Department/Communication Science Study Program, Social Sciences, the results of this study can be useful as information and input material for developing communication research and communication theory; 2) For the community Manggarai in the city of Kupang, the results of this study can be useful as important information material in understanding Nempung as a must for traditional Manggarai marriages. This paper is expected to be useful as inspiration for further developing Clay in the future; 3) For other readers, this article is expected to be useful as information material to better understand Nempung as one of the most important stages as adat legitimacy for the marriage of two human children in Manggarai Raya, East Nusa Tenggara Province.

\section{Literature Review}

\subsection{Communication}

Communication is a process of human activity that is expressed through spoken and written language, images, signals, sounds and various other forms of code 
that contain meaning and are understood by others (Gunadi, 1998: p. 69). But the word communication actually contains participatory meaning in a relationship with another or someone else. The meaning is very clear when we explore the lexical meaning. The word communication is rooted in the verb Communicate and the noun Communication in Latin (Carvallo and Verhoeven, 1969: p. 176). The word communicate has several meanings, that is, making things public, sharing with others, giving part to, taking part in, telling others, talking with, associating with, united with, etc. While the term communication means taking part in, giving part in, relationship, etc. Based on this lexical understanding, it is clear that the word communication contains participatory meaning in interaction with others.

Many definitions of communication have been put forward by experts, including the following. First, Howland, Janis and Kelley, American sociologists, define communication as the process by which individuals transmit stimuli (usually verbal) to modify the behavior of other individuals. Communication is the process of individuals sending stimuli that are usually manifested in verbal form to change the behavior of others. In this definition, communication is clearly considered as a process, not as a matter. Secondly, Forsdale (1981), communication expert and education expert defines: communication is the process by which a system is established, maintained and altered by means of shared signals that operate according to rules. Communication is a process of giving signals according to certain rules, so that in this way a system can be established, maintained and changed. By definition, communication is also considered as a process.

Third, Brent \& Stewart (2013) define human communication more comprehensively. Human communication is the process through which individuals in their relationships, in groups, organizations and in society, seek to create, transmit and use information to coordinate their environment and others. Fourth, $\mathrm{Mu}-$ lyana (2001) provides a more universal definition of communication. He said communication is the process by which verbal and non-verbal symbols are sent, received and given meaning. Fifth, according to Arni Muhammad, communication is the exchange of verbal and nonverbal messages between the sender and the recipient of the message to change my behavior. The sender of the message can be a person/individual group or organization. So is the case with the recipient.

In the concept of communication contained many dimensions that can be distinguished but not separated from each other. in human life, communication has a number of functions: 1) social function which is a means to connect with others; 2) expressive function, namely as a tool to express thoughts, feelings etc.; 3) the function of ritual is a means to connect with the Supreme Being (God) and 4) instrumental functions, namely as a tool to meet various needs in human life and society. In essence, communication can be distinguished from human communication or personal communication and non-personal communication 
or infra-human communication such as animal communication, communication of material nature or the nature of creation. Human communication or personal communication includes intrapersonal communication, interpersonal communication, group communication, public communication, organizational communication, and mass communication etc.

Then, quoting the opinions of Wenburg \& Wilmot (1973: pp. 61-69) in $\mathrm{Mu}-$ lyana, distinguishes three frameworks of understanding or conceptualizing the word communication namely 1) communication as a one-way action, 2) communication as interaction and 3) communication as transactions in the context of face to face with others. The concept of communication contains a number of inseparable principles namely that communication is 1) a symbolic process, 2) manifested through behavior, 3) has dimensions of content and relationships, 4) takes place in various levels of intentionality, 5) occurs in space context and time, 6) involves prediction of communication participants, 7) is systemic, 8) is non-consequential, 9) is processual, dynamic and transactional, 10) is irreversible. In addition, 11) the more socio-cultural background of communication participants, the more effective a communication is, and 12) communication is also not a panacea for solving problems.

Communication also has many models that are broadly divided into linear models, interaction and participatory models and transactional models. several linear communication models such as the SR model, the Aristotelian model, the Lasswell model, the Shannon and Weaver model, the Schramm model, the Newcomb model, the Westley and Maclean model, the Gerbner model, the Berlo model, the De Fleur model, the Tubbs model, the Gudykunst and Kim model, the participatory communication model, model interaction communication and transactional communication model (face to face) etc. The essence of communication is perception. A perception is created based on one's experience of an object in another person's relationship, with nature and with God.

\subsection{Cultural Communication}

The term cultural communication is one aspect of human communication $(\mathrm{Hu}-$ man Communication). According to Tubbs, intercultural communication is communication between people of different cultures both in terms of race, ethnicity or socio-economic differences. In the book "Intercultural Communication: a Reader", intercultural communication occurs when a message that must be understood is produced by members of a particular culture, for the consumption of members from other cultures (Samovar, Mc Daniel, \& Porter, 2010).

The aims of cultural communication include: 1) understanding cultural differences that influence communication practices, 2) broadening communication between people of different cultures, 3) identifying difficulties that arise in communication, 4) helping to overcome the communication problems caused by cultural differences, 5) improving verbal and non-verbal skills in communication, 6) making us able to communicate effectively. 
As a cultural unit, the Manggarai community has ideas about patterns of relationships and communication with others, nature and with God or Mori Kraeng, Morin Agu Ngaran, Jari Agu Dedek. Through the expression of its communication culture, the community as a supporter of Manggarai culture expresses ways/ mindsets, self-concepts and conceptions about the nature of the relationship. Communication culture is an integral part of the concept of a particular society's culture when culture gives contextual meaning to the communication activities of its citizens.

Marriage communication is an integral part of people's culture. In his book entitled Communication as Culture (1989), James W. Carey firmly states that the act of communication in social life is nothing but an integral part of the culture of that society. Communication culture is a habit of thought and action that reflects the culture of the supporting community where it is because the communication culture action departs from the pattern of thinking, attitude and perception of the community itself about the nature of life which includes the unity of relationships humans with each other, with nature and human relationships with the highest form. According to De Vito (De Vito, 1997: p. 23), communication refers to the actions of one or more people, who send and receive messages that are distorted by noise, occur in certain contexts, have a certain influence and have the opportunity to bait behind. According to Everett Rogers, communication means the process of achieving mutual understanding several other communication experts assert that there is no time without communication in human life as social cultural beings. In a life together, humans always communicate because they always create message symbols whether verbal or non-verbal. In the communication process, there is a message display and interpretation at the same time.

\subsection{Communication Symbols}

\subsubsection{What Is a Symbol?}

Symbols (Latin word Symbolicum, Greek Sumbolon = sign interpreting something) is a symbol used to represent a specific purpose, for example in verbal words spoken/written or nonverbal symbols that are exhibited through gestures of the body, color artifacts, images, clothing and others. Symbols are symbols that have an object while the code is a set of symbols that have been arranged systematically and regularly so that it has meaning. A symbol that has no meaning is not a code, says Berlo (1960). Syam (2009: p. 42) revealed that symbols reveal something that is very useful for communication. Thus symbols have an important role in the process of communication. In the study of symbolic interactionism, the symbols themselves are created and manipulated by the individuals concerned in order to gain an understanding of both themselves and the community.

Symbols in culture are part of communication. Symbols are a clue in broadening the horizons of cultural societies. The communication process is the process of meaning of these symbols. Through this interpretation then humans 
find out and share about reality. Geert (in Sobur, 2006: p. 178) states that culture is a pattern of meanings contained in symbols passed down through history. Culture is a system of concepts which are inherited and expressed in symbolic forms through which humans communicate, perpetuate and develop knowledge about culture and behave towards this life.

\subsubsection{Communication Symbol}

Basically, symbols are interpreted both in verbal and non-verbal language forms in their meanings. The real form of this symbol interaction occurs in communication activities. When a communicator emits a signal (message) both verbal and nonverbal, communication tries to make sense of the stimuli. This is where a social process occurs where both parties try to contribute to the communication process that occurs at that time. Therefore, communication cannot actually be seen as a simple process as a form of interaction between symbols, but furthermore, communication is a process of meaningful interactions contained in the symbols used.

Thus, the communication process can also be a means used to introduce something to other parties through symbols that are used to convey a message. as for the symbol or symbol here concerning verbal symbols conveyed by using language and also symbols that are shown through material, color and other supporting things (Gayes, 2012) philosophically, the cosmic substance can mediate and enhance communication between subjects (people) with other cosmasters (partners), whether they are tools, signs or symbols. All have the same communication structure so that the three cosmic substances that communicate at once unite and are distinguished and mutually causing each other. This mediation is basically permanent-new and quantitative-qualitative. The characteristics of tools, fivepointed signs and symbols and their characteristics are modified in accordance with the higher level of inter-communication density between subjects and partnerswith symbols as peaks (Bakker, 1995: pp. 266-267). Types of communication symbols come from humans, animals, plants and inanimate objects.

Humans are the prototype of all tools, signs and symbols because he lives their characteristics in the most complete and complete way. But between tools, signs and symbols, there is a hierarchy of densities according to a hierarchy of cosmic levels. Tools, signs and symbols function in cosmic sociality in various forms and according to their level of density. The use of historical-character tools, signs and symbols, becomes permanent and new, according to the birth and death as a means of communication, essentially, its function as a means and results of its communication. But permanence, according to its density and is always accompanied by novelty too. The possible use of tools, signs and symbols is not based on physical-spirituality, but based on the intrinsic intercommunication relationship between cosmos-cosmos in nature, but bodily-spirituality contributes to the universe throughout the implementation of its communication (Bakker, 1995: pp. 266-267). 


\subsection{Perspective of Communication Interaction Theories}

\subsubsection{Theory of Symbolic Interactionism}

The focus of this theory is meaning and action. In everyday life, people can have different meanings about events and communication actions. Communication acts as meaningful social actions based on individual subjective meanings. His actions take into consideration the behavior of others and are therefore oriented in appearance (Mulyana, 2001). Ralph LaRossa and Donald Creitzes (Santoso and Setiansah, 2010: pp. 21-24) noted seven assumptions underlying the theory, which showed three major themes namely 1) The importance of meaning for human behavior; 2) The importance of self-concept and 3) Relations between individuals and society. Regarding the relevance and urgency of meaning, Blumer (1969) assumed that: 1) Humans acted against other humans based on the meanings of others to them. 2) Meanings are created in interactions and 3) Meanings are modified in interpretive processes. Blumer puts forward three basic principles of symbolic interactionism related to meaning, language, and thought.

\subsubsection{Dramaturgy Theory}

Dramaturgy is a play of human life. The focus of dramaturgy theory is how they do it. Dramaturgy emphasizes the expressive and impressive dimensions of human activity. Social life is divided into front and back regions. The front area refers to social events that show individuals displaying their formal role. The back region refers to places and events that allow him to prepare for his role in the front area. The front stage area is divided into two parts, namely the private front and the private front setting consisting of tools that are deemed appropriate as the equipment carried by the actor into the setting. the personal front includes the actor's verbal and body language such as speaking politely, saying unfamiliar terms, expressing faces, displaying clothes, voice intonance, body posture, showing age, etc. All that are controlled by the actor. Setting is a physical situation that must exist when the actor gives a performance (Mulyana, 2004: p. 115). In our society, marital communication between tribes is carried out using media that manifests symbolic actions. In ceremonial communication interactions, the participants of the ceremony express symbols that contain certain meanings.

\section{Research Method}

\subsection{Type of Method Used}

In accordance with the intent and purpose, in this study researchers used a type of qualitative research methods (Denzin and Lincoln, 1994; Alwasilah, 2002; Mulyana, 2001; Moleong, 2001) with case study variants (Yin, 2002). Qualitative research methods, with case study variants trying to exploit the substance of the meaning of Nempung in the Manggarai traditional marriage insofar as it was carried out in Kupang descriptively.

Qualitative research with case study variants explains information that is not widespread because it only examines the phenomenon of communication sym- 
bols that are revealed in the traditional marriage of Manggarai in Kupang. But the research is very in-depth because the study process starts from the basis of the case to be investigated. be explored in this context, researchers do not build logical deductive reasoning like quantitative research methods but rather try to build substantive theories based on empirical data.

\subsection{Key Informers}

Decisions about key informants who can inform the data of Nempung research in Manggarai traditional marriage communication in the city of Kupang basically depends on the determination of a research study unit. This research study unit covers the Manggarai community in Kupang. therefore, there are three classifications of informants who were interviewed in depth (depth interview) in this study: 1) Customary leaders from West Manggarai Regency, especially traditional leaders domiciled in the city of Kupang; 2) Customary leaders from Manggarai Regency, especially traditional leaders domiciled in Kupang city; 3) Customary leaders from East Manggarai Regency, especially those who live in the city of Kupang.

\subsection{Data Collection Technique}

Research data collection techniques are done by 1) Participant observer, 2) in-depth interviews (depth interviews), 3) focus group discussions. As Participant Observer means that the researcher himself is directly involved in the implementation of the Nempung/Wagal ceremony in the process of communication of the Manggarai traditional marriage in Kupang, which functions as the organizer and central part of the Nempung implementation. Researchers as well as organizers as observers and make observations. In-depth interviews were conducted with traditional figures and Manggarai community leaders who were directly involved in the Manggarai traditional marriage communication process such as the Teing tongs and the Arriving Tongka, Manggarai cultural observers. The focus group discussion was conducted in a group of peers who had already passed through the Manggarai traditional marriage communication process in Kupang.

\subsection{Data Analysis to Be Done}

In data analysis, researchers used three activities. First, to reduce data, which is to sharpen and classify primary data sourced from parties directly involved in Nempung communication, primary data from tongka and so on. Second, researchers sort the data carefully and carefully, discard data that is less relevant to the object of case study research, describe the data in detail and organize the existing data to draw conclusions correctly. Third, after obtaining the results of the analysis of research data, the researcher then explains, interprets or interprets the data and information to look for a broader and more profound meaning regarding the traditional marriage of Manggara. For that, the results of this study need to be linked to the results of other similar/similar studies that have been 
done so that we can enforce the balance of research results.

\subsection{Data Checking and Validity Techniques}

Data validity checking techniques in this study: 1) Extend participation. 2) Make diligent and careful observations. 3) Triangulate. 4) Conduct a negative case analysis. 5) Do a thick description. 6) Have discussions with peers. 7) Referring to enough references. 8) Auditing.

\section{Research Results and Discussion}

The results of interviews conducted with Manggarai community leaders, as the Tongka Teing and Tongka Tiba namely Mr. HM (July 25, 2019) in Deru, Lamba Leda District, explained that: the clay event as a traditional rite by reciprocating communication between Tongka Teing (the bride and groom men) and Tongka Tiba (bride) during a wedding event. Nempung invites God's intervention as the creator and asks for the blessing of the ancestors. An interview was also conducted to Mr. AN (November 26, 2019) in Kupang by explaining that, the clay was a series of traditional events to pay off the traditional with a ceremony of Renge (traditional song by Tongka Tiba) to ask for the blessing of God and ancestors in the marriage. Nempung as a traditional Manggarai wedding ceremony which is blessed in continued with the Roko (wedi ruha) event. The roko show as a traditional rite of the bride is included in the groom's family. The process of displaying messages in communication Manggarai traditional wedding matrices provides important messages for new families and strengthens the bond of relations between the two extended families both male and female families.

The process of displaying messages in communication Manggarai traditional wedding matrices provides important messages for new families and strengthens the bond of relations between the two extended families both male and female families. The following messages were concluded based on discussions with a group discussion conducted at Unika Widya Mandira totaling 5 people on December 14, 2019. The results of the discussions conveyed the following traditional communication messages.

The first message, the Nempung rite invites the intervention of the Supreme Being (Glossary Verhejyen) or Morin agu Ngaran, Jari agu Dedek, for newlyweds who unite as husband and wife and ask for the blessing of ancestors (family members who have died) as seen from the contents of Tudak Nempung (Prayer custom Snuff) and yelling Teing Hang (Feed ancestors).

The second message, the Nempung affirmation of the presence and support of the prayer of the traditional elders and the two extended families in witnessing, blessing and supporting the marriage of the two newlyweds as seen in the phenomenon of communication Tudak Nempung. The third message, the Nempung communication event gave Manggarai customary legitimacy to the union of the bride and groom as husband and wife as seen in the symbolic actions of Renge Ela Dara Wa' is communication. 
The fourth message, the Nempung communication event stated the love relationship between the bride and groom (eternal and permanent family relationship) between the two extended families that fostered kinship as revealed through the expression Wae Teku Tedeng, the Salang tuak bomb. Meaning that the relationship is eternal like drawing water throughout life, not like taking a wine only limited to the morning and evening. Two tribes that had not had a kinship, with these two brides, two families who came from different tribes, began to develop relationships and have a lasting kinship.

The fifth message, the Nempung incident demonstrates, reveals and states the message of communication actions of Anak Rona Ulu who are very important in maintaining, protecting, accommodating and being a source of fortune for the life of her niece who forms a new family. Clam in traditional marriage consists of two extended families and related families. Symbolic communication interaction between family of women and family of men and supported by the family of Anak Rona Ulu. Since the beginning of the express communication process, the big family of men and large families of women exhibit the actions of human communication symbols that include front stage communication and back stage communication as seen in the theory of symbolic interactionism and dramaturgy theory Nempung symbols.

First, human symbols as prototypes of the universe are revealed in verbal and nonverbal language symbols that express the meaning of Nempung and give the message of the uniqueness of Manggarai civilized people. Verbal communication is expressed through traditional language that is polite and meaningful. Nonverbal communication is expressed in the attitudes, behaviors and deeds and reception of male family guests who are supported by commensurate speech. The two extended families foster a permanent family relationship (woe) based on lasting love. Salang wae, wae teku tedeng.

Second, animal/pet symbols such as buffaloes, horses, pigs, goats and chickens, each of which has its own values and meanings in relation to new family life. White chicken which was sacrificed during Teing Hang Kilo and Teing Hang Wura agu Ceki from both big families (male family and female family), symbolizing purity and purity and sincerity of heart to undergo a kinship based on love. Pets that are made into belis such as buffaloes and horses etc are symbols of love and sacrifice for the family of men to knit family ties and kinship with the family of women. Thus, the women's family responded with the sacrifice of pigs as a symbol of women's family love for the sacrifice of the male family.

Third, symbols of materials and tools for the necessities of human life such as machetes (kope), traditional cloth Manggrai (towe songke), dulang, sack rice, each of which has its own meaning in relation to new family life in the future. a) Human symbols are meaningfulas a symbol of communication actions of the two big families to support a new family life better. Good and ethical communication processes at Nempung become a blessing for new families to build their better lives in the future. On the other hand, the poor communication and prob- 
lematic Nempung, signifying a new family life full of challenges in the future such as illness and illness, etc. b) Animal care for Manggarai families (Farmers) such as buffalo, horses, cows, goats and chickens (white) are an inseparable part of Manggarai's daily life. bring belis (bring Paca) from pets during communication The clay became a meaningful symbol as a willingness to sacrifice his own valuable animal for the sake of his love for the girl /family of the woman he wanted to edit and related families to build permanent kinship (Woe). c) Materials and equipment for daily necessities such as machetes (kope banjar), traditional cloth (Nael Towe Songke), dulang and rice are an essential and inseparable part of the daily life of Manggarai peasant families. By providing materials and equipment to meet the needs of life is a symbol of communication actions Anak Rona Ulu (uncle) to be a source of fortune, to protect and maintain the life of a new family (nephew) from all future challenges.

First, machete (kope) is a symbol of the actions of Rona Ulu (om biological) child in opening and clearing the way for a new family, so that the bride and groom's new family journey runs smoothly, without obstacles. Second, Dulang is a container for putting important and valuable items. this is a symbol of the actions of the rona ulu child to provide a sturdy container for the new family third, Sack rice is a symbol of giving fortune from Anak Rona Ulu to a new family so that they have enough stock in navigating the ocean of life that is full of challenges newly weds so that new families avoid the cold during the journey to a better future.

There are many reasons why couples do not carry out the Nempung event, among which, the Nempung stage is expensive and therefore requires adequate preparation. In the case of Nempung, Belis alias Paca is usually paid in full. Besides the cost factor, the influence of the Catholic religion which believes that marital safety does not depend on the legitimacy of adat but rather on love between partners. Is that really the case? This requires further research.

Therefore, the Manggarai husband and wife who have not yet implemented Nempung, their marriage has not been declared legally customary. according to the beliefs of Manggarai people who still hold fast to customs, marriage between husband and wife without the process of clay gets various kinds of real sanctions such as no offspring, various household problems arise etc. if the sanction has not been felt in the first layer offspring, can occur in the second layer offspring and so on. This is certainly based on observations and experiences that are seen.

\section{Conclusions and Suggestions}

\subsection{Conclusion}

Based on the discussion of the results of the study, conclusions can be drawn, first, the three events of the Nempung case study in Kupang city have unique message communication characteristics each due to differences in circumstances and the underlying conditions. However, all three events also show a fundamental similarity. In the event of Nempung communication, a symbolic communica- 
tion interaction took place between two big families, both male and female families. Second, important communication symbols in Nempung events in Manggarai traditional marriage, including humans, animals, equipment used to meet the needs of life. Third, Nempung communication symbols contain deep meaning and meaning for Manggarai human life in general and the life of the newly wed in building a new family's vision and mission especially in daily life.

Fourth, implementing Nempung for a new family according to Manggarai custom should be very important for the traditional legitimacy of the marriage of two people who want to live together to form a family as husband and wife. But by the influence of the times, the tendency of Nempung is ignored by some Manggarai marriage couples. Even the marriage of two people is bypassed by a shortcut, without customary affairs. For Manggarai people who hold fast to the Manggarai custom, Nempung as the culmination of adat marriages must be carried out so that new family life based on the Manggarai custom gets safety. But for some Manggarai people who do not believe in the traditional Nempung as a guarantee of the safety of the bride and the future of the family that is built, consider Nempung as something unimportant and simply ignored.

\subsection{Suggestion}

Suggestions submitted to various related parties are as follows. First, for the bride and groom of the Manggarai people today, the results of this study are expected to be useful as information material to better live up to the importance of adat legitimacy for their marriages as traditionally legal entities. Marriages that have not yet implemented Nempung are not yet legitimate and legitimate in the traditional Manggarai tradition.

Second, for Manggarai parents both in Manggarai Raya and outside Manggarai Raya, the results of this study are expected to be useful information and inspiration sources to further strengthen their belief in the importance of traditional legitimacy of their marriages and to the traditional marriage of future generations of Manggarai.

Third, for the Manggarai community, the results of this study are expected to be information material to understand the nature of marriage from the perspective of traditional Manggarai and be an inspiration to continue to believe that the communication event of the Manggarai traditional wedding nempung is a moment Customary legitimacy must be maintained for a legimated marriage in a traditional Manggarai manner.

Fourth, for universities and other research institutions, the results of this study are expected to be material information to carry out further research on the relevance of Nempung communication events today.

\section{Conflicts of Interest}

The authors declare no conflicts of interest regarding the publication of this paper. 


\section{References}

Alwasilah, A. C. (2002). Basically Qualitative, Basics of Designing and Conducting Qualitative Research. Jakarta: The Cooperation of PT. Pustaka Jaya World with Sundanese Study Center, Matter I.

Bakker, A. (1995). Antropolgi Metafisik. Yogyakarta: Kanisius.

Berlo, D. K. (1960). The Process of Communication: An Introduction to Theory and Practice. New York: Holt, Rinehart and Winston.

Blumer, H. (1969). Symbolic Interactionism; Perspective and Method. Englewood Cliffs, NJ: Prentice-Hall.

Brent, D. R., \& Stewart, L. P. (2013). Komunikasi dan Perilaku Manusia. Jakarta: PT Raja Grafindo Persada.

Carvallo, M., \& Verhoeven, L. (1969). Kamus Latin Indonesia. Ende: Nusa Indah.

De Vito, J. (1997). The Interpersonal Communication. Pennsylvania: Pearson Educations Inc.

Denzin, N. K., \& Lincoln, Y. S. (1994). Handbook of Qualitative Research. Thousand Oaks, CA: Sage Publication Inc.

Forsdale, L. (1981). Perspectives on Communication. New York: Random House.

Gayes, M. (2012). The Intersubjective World of Kebayat Community, Thesis, Unpad, Bandung.

Gunadi, Y. S. (1998). Himpunan Istilah Komunikasi. Jakarta: Grasindo.

Moleong, L. J. (2001). Metodologi Penelitian Kualitatif. Bandung: PT Remaja Rosda Karya.

Mulyana, D. (2001). Communication Studies, An Introduction (2nd ed.). Bandung (ID): PT Remadja Rosda Karya.

Mulyana, D. (2004). Qualitative Research Methodology, New Paradigm of Science Communication and Other Social Sciences. Bandung: PT. Remadja Rosdakarya.

Samovar, L. A., Mc Daniel, E. R., \& Porter, R. E. (2010). Intercultural Communication a Reader (9th ed.). Belmont: Wadsworth.

Santoso, E., \& Setiansah, M. (2010). Communication Theory (Prints I). Yogyakarta: Graha Science Publishers.

Sobur, A. (2006). Semiotika Komunikasi. Bandung: Remaja Rosdakarya.

Syam (2009). Tantangan Multikulturalisme Indonesia. Yogyakarta: Kanisius.

Wenburg, J. R., \& Wilmot, W. W. (1973). The Personal Communication Process. New York: John Wiley.

Yin, R. K. (2002). Case Study Research, Design and Methods (Third Printing). Jakarta: PT Raja Grafindo Persada.

\section{Teaching Materials}

Darus Antonius, 2017. Instructional Materials Social Research Methodology. Kupang (ID): Communication Studies at FISIP, Unwira, Kupang.

Darus Antonius, 2017. Instructional Materials Communication Research Methodology 1. Kupang (ID): Communication Science FISIP Unwira, Kupang.

Darus Antonius, 2016. Teaching Materials Communication Research Methodology 2. Kupang (ID): Communication Science FISIP Unwira, Kupang.

Darus Antonius, 2016. Organizational Communication Teaching Materials. (ID): Communication Science FISIP, Unwira Kupang. 
Darus Antonius, 2016. Teaching Materials for Communication Theory. (ID): Communication Studies, Social Sciences, Unwira, Kupang.

\section{Informant}

Henrikus Man, 64 Years Old, a Tongka (spokesman) of Manggarai Custom, Lives in Benteng Jawa, East Manggarai.

Frans Ganggas, 55 Years Old, a Tongka (spokesman) of Manggarai Custom, Lives in the City of Kupang, NTT.

Sebas Dasar, 60 Years Old, Traditional Manggarai Expert, Usually Brings Tudak Nempung, Anak Rona Tueng, Lives in the Copu Village, Cibal District, Manggarai Regency.

Laurens Daud, 59 Years Old, Had Been a Tongka (spokesman) in Traditional Manggarai Marriage, Living in Deru Village, East Manggarai Regency.

Johanes Jehanis, 66, a Community Leader, Lives in Benteng Jawa, East Manggarai Regency.

Marsel Ukar, 61, a Traditional Spokesman for Manggarai (a Tongka), Lives in the City of Kupang, NTT.

Petrus Agut, 62, a Traditional Spokesman for Manggarai (Tongka), Resides in Kupang City, NTT.

Prof Dr Frans Bustan, 65 Years Old, Traditional Expert in Manggarai, Works as a Lecturer in English, Undana, Kupang, NTT.

Maxi Gurang, a Tongka (Spokesman) of Nanggung Manggarai Marriage.

Avelinus Juru, 64 Years Old, Traditional Leader of Langke, Rahong Utara District, Manggarai Regency.

Yoakim Sair, 58 Years Old, Traditional Leader, Carrier of Tudak Nempung Roby-Vira, Lives in Lenang Village, Poco Ranaka Sub-District, East Manggarai.

Laurens Zaman, 60 Years Old, Traditional Figure, Spokesperson ( Tongka) of Manggarai Traditional Marriage, Lives in Lenang, Poco Ranaka District, East Manggarai.

Bernadus Daguk, 52, a Community Leader, Lives in Benteng Jawa, East Manggarai Regency. 